\title{
FLORA DE GRÃO-MOGOL, MINAS GERAIS: XYRIDACEAE ${ }^{1}$
}

\author{
MARIA DAS GRAÇAS LAPA WANDERLEY * \& MARIA BERNADETE COSTA E SILVA** \\ *Instituto de Botânica, Secretaria do Meio Ambiente, Caixa Postal 4003 - São Paulo, SP, Brasil \\ Endereço para correspondência: gracaw@terra..com.br \\ ** Herbário IPA-Dárdano de Andrade Lima, Av. General San Martín, 137, Bongi. 50761-000 - Recife, PE, Brasil
}

Kral, R. 1988. The genus Xyris (Xyridaceae) in Venezuela and contiguous northern South America. Ann. Missouri Bot. Gard.75: 522-722.

KraL, R. 1992. A treatment of american Xyridaceae exclusive of Xyris. Ann. Missouri Bot. Gard. 79: 819-885.

Kral, R., Smith, L.B. \& Downs, R.J. 1982; Xyridaceae Brasiliae - II. Bradea 3: 273-298.

Kral, R. \& Wanderley, M.G.L. 1993. Five new taxa of Xyris (Xyridaceae) from Brazil. Kew Bull. 48(3): 577-588.

Seubert, M. 1855. Xyrideae. In C.F.P. Martius \& A.G. Eichler (eds.) Flora brasiliensis. Frid. Fleischer. Leipzig, vol. 3, pars 1, p. 209-224, tab. 22-30.

Sмith, L.B. \& Downs, R.J. 1965. Xyridaceae. In R. Reitz (ed.) Flora ilustrada catarinense. Herbário Barbosa Rodrigues. Itajaí.

Sмith, L.B. \& Downs, R.J. 1968. Xyridaceae. In A.R. Teixeira (ed.) Flora brasilica. Instituto de Botânica. São Paulo, vol. 9(2), fasc. 12 , p. 1215 , tab. $1-42$.

Wanderley, M.G.L. 1989. Xyridaceae. In J.A. Rizzo (coord.) Flora do estado de Goiás: Coleção Rizzo. Cegraf/UFG. Goiânia, vol. 11, p. 1-81, fig. 1-15, 27 mapas.

Wanderley, M.G.L. 1992. Estudos taxonômicos no gênero Xyris (Xyridaceae) da Serra do Cipó, Minas Gerais. Tese de doutorado, Instituto de Biociências, Universidade de São Paulo, São Paulo.

Wanderley, M.G.L. 2003. Xyridaceae. In M.G.L. Wanderley, G.J. Shepherd, A.M. Giulietti, T.S.A. Melhem, A.M. Giulietti \& M. Kirizawa (eds.) Flora fanerogâmica do estado de São Paulo. FAPESP, Rima. São Paulo, vol. 3, p. 333-348.

\section{Xyris Gronov. ex L.}

Ervas perenes, raramente anuais, cespitosas ou solitárias, rizomatosas, rizomas em geral com entrenós curtos. Folhas poucas a numerosas, geralmente rosuladas, espiraladas, dísticas ou subdísticas, equitantes, geralmente verdes, glaucas, castanhas ou ferrugíneas; bainha aberta, muito a pouco distinta da lâmina, margem ciliada a glabra; lígula presente ou ausente; lâmina achatada, cilíndrica, subcilíndrica a filiforme, pilosa a glabra, superfície foliar lisa, nervada, rugulosa ou escabra, ápice reto ou recurvado. Escapo cilíndrico, subcilíndrico, achatado a filiforme, costelado ou não, mais raramente alado, piloso a glabro, superfície lisa, nervada, rugulosa a escabra. Espiga terminal, pauci (até 10 flores) a multiflora (mais de 10 flores), elipsóide, ovóide a obovóide, com numerosas brácteas imbricadas espiraladas, côncavas, geralmente castanhas, com ou sem mancha verde ou avermelhada na face dorsal, carenadas ou não, pilosas a glabras, com margens íntegras a laceradas, ciliadas a fimbriadas, algumas vezes de coloração distinta. Flores trímeras; sépalas 3, a anterior em geral membranácea, cupuliforme e avermelhada, caduca na antese; as 2 laterais naviculares, carenadas, carena ciliada, fimbriada, escabra ou glabra, livres ou parcialmente soldadas, pétalas 3, amarelas, livres, unguiculadas, lobos expandidos; estames 3, epipétalos, anteras rimosas; estaminódios 2, bífidos, pilosos ou raramente glabros; ovário súpero, tricarpelar, unilocular ou raramente trilocular, estigma trífido, óvulos numerosos, funículos longos a curtos; placentação basal, suprabasal, central-livre ou parietal. Fruto cápsula loculicida; sementes poucas a numerosas, pequenas, estriadas ou reticuladas.

Xyridaceae é constituída por cerca de 400 espécies distribuídas em cinco gêneros, sendo cerca de $90 \%$ pertencentes ao gênero Xyris, que é amplamente distribuído no Brasil, especialmente nos campos rupestres de Minas Gerais e Bahia. Em Grão-Mogol há registros até o momento de 18 espécies do gênero Xyris.

\footnotetext{
${ }^{1}$ Trabalho realizado conforme o planejamento apresentado por Pirani et al. (2003). Bol. Bot. Univ. São Paulo 22(1): 1-24.
} 
1. Plantas anuais; estaminódios glabros; espiga largo-ovóide

X. savanensis

1'. Plantas perenes; estaminódios pilosos; espiga elipsóide, ovóide a obovóide.

2. Placentação parietal; brácteas com mancha conspícua na face dorsal.

3. Escapo multicostelado; bainha foliar carenada e fortemente estriada; estigmas pouco alargados; fruto ovóide X. fallax

3'. Escapo em geral sem costelas ou 1-costelado; bainha foliar não carenada, lisa ou estriada; estigmas alargados; fruto obovóide X. laxifolia

2'. Placentação basal, supra-basal ou central-livre; brácteas com ou sem mancha na face dorsal.

4. Placentação basal; sépalas laterais livres; brácteas sem mancha, ou quando presente não ocupando cerca da metade da superfície da face dorsal.

5. Brácteas estéreis mais de 4; folhas flexuosas.

6. Folhas poucas (ca. 6); espiga cilíndrica; brácteas estéreis 8 , oblongas a obovadas, as 2 externas muito curtas e as internas gradativamente maiores, com mancha conspícua a inconspícua X. sparsifolia

6 '. Folhas numerosas; espiga ovóide a globosa; brácteas estéreis 6 , oval-lanceoladas, as 2 externas pouco mais curtas até muito maiores que as demais, sem mancha X. sincorana

5'. Brácteas estéreis 4; folhas retas, algumas vezes levemente torcidas.

7. Brácteas com margens distintas, laceradas, alvacentas ou vermelho-ferrugíneas.

8. Brácteas com margens persistentes, vermelho-ferrugíneas; folhas com lâmina achatada e conspicuamente ciliada; escapo 2-costelado ou 2-costado.

9. Brácteas com mancha larga, ovada e conspícua, fortemente carenadas; sépalas laterais com carena estreita e curtamente ciliada X. graomogolensis

9'. Brácteas sem mancha, não carenadas; sépalas laterais com carena larga, lacerado-fimbriada X. roraimae

8'. Brácteas com margens alvacentas, caducas; folhas com lâmina cilíndrica a achatada, glabra ou escabra; escapo sem costelas ou 1 a multicostelado.

10. Escapo 1 a multicostelado, conspicuamente ruguloso ou escabro; brácteas com pequena mácula apical X. tenella

10'. Escapo sem costela ou 1-costelado; brácteas sem mácula.

11. Base da planta bulbiforme; folhas torcidas, lâmina em geral cilíndrica X. tortula

11'. Base da planta não bulbiforme; folhas retas, lâmina achatada X. hymenachne

7'. Brácteas com margens pouco distintas, concolores, íntegras ou levemente laceradas.

12. Folhas e escapo rugulosos, escabros e ásperos; margens da lâmina escabro-ciliadas; escapo sem costelas X. asperula

12'. Folhas e escapo lisos ou inconspicuamente rugulosos; margens da lâmina conspicuamente ciliadas; escapo em geral 2-costelado, costelas ciliadas (raramente sem costelas).

13. Folhas com bainha estramínea, lâmina verde-clara; brácteas estéreis em geral com mancha conspícua; placentação suprabasal X. obcordata

13'. Folhas com bainha castanha, lâmina castanho-avermelhada; brácteas estéreis em geral sem mancha conspícua; placentação basal

X. pterygoblephara

4'. Placentação central-livre; sépalas laterais conatas; brácteas com mancha ocupando cerca da metade da superfície da face dorsal ou estreita e apical.

14. Bainha densamente pilosa, tricomas longos e vilosos, formando trama Xyris sp. 1

14'. Bainha glabra, ciliada, escabra, rugulosa, quando ciliada com tricomas mais curtos e não formando trama.

15. Folhas com lâminas filiformes a subcilíndricas; bainhas tortuosas, margens membranáceas e paleáceas; brácteas com margens membranáceas, distintamente mais claras, alvacentas e ciliadas X. calostachys

15'. Folhas achatadas; bainhas retas, margens pouco distintas; brácteas com margens pouco distintas e quando distintas avermelhadas, glabras ou ciliadas apenas no ápice.

16. Escapo levemente comprimido, 2-costelado, costelas escabras; sépalas concrescidas na base, carena com tricomas vermelhos X. trachyphylla

16'. Escapo cilíndrico; sépalas concrescidas até a metade, carena com tricomas alvos ou avermelhados.

17. Escapo multicostelado; brácteas com ápice não excurrente; carena das sépalas com tricomas alvos $X$. glaucescens

17. Escapo 1-2-costelado; brácteas com ápice em geral excurrente; carena das sépalas com tricomas vermelhos X. seubertii var. espinhacae 


\subsection{Xyris asperula Mart., Flora 24(2): 57. 1841.}

Ervas cespitosas ou isoladas, perenes; rizoma vertical curto, espesso, base da planta alargada, bulbiforme. Folhas espiraladas, algumas vezes torcidas, 17-33 cm compr.; bainha castanho-escura, margens ciliadas a glabrescentes; lâmina achatada, 1-3 mm larg., estriada, rugulosa, escabra, em geral áspera, margens escabro-ciliadas. Escapo cilíndrico, sem costelas, 75-88 cm compr., ruguloso, escabro, em geral áspero; espata conduplicada, 10-16 cm, lâmina curta, ca. 2 $\mathrm{mm}$ compr. Espiga multiflora, cilíndrica, globosa a ovóide, 1-1,5 cm compr., 0,6-1 cm larg.; brácteas estéreis 4, castanhas, sem mancha, coriáceas, obovadas a ovadas, 5-6 mm compr., 3-4 mm larg., concolores, margens irregularmente laceradas quando velhas; brácteas florais oblongas a obovais, 7-8 mm compr., 5-6 mm larg. Flores com sépalas laterais inclusas a levemente exsertas, livres, lanceoladas, ca. $7 \mathrm{~mm}$ compr., inequilaterais, carena ciliada; estaminódios densamente pilosos. Placentação basal. Sementes ca. 0,7 mm, castanho-escuras, estriadas.

Simão-Bianchini et al. CFCR 12968 (SPF); Kral et al. 72694 (SP, SPF); Pirani 4661 (SPF, SP).

A espécie distribui-se desde o Brasil Central até o Paraná, sendo frequente nos campos rupestres e ambientes de cerrado da Cadeia do Espinhaço nos estados de Minas Gerais e Bahia. Em Grão-Mogol habita solos arenosos e alagados no vale do rio Itacambiruçu e à beira do riacho Ribeirão. Apresenta ampla variação quanto ao tamanho e forma da espiga, sendo bem característica pela base da planta bulbiforme, rizoma robusto e curto, apresentando forte brotação lateral. As folhas e o escapo são, em geral, escabros e ásperos. Flores e frutos em junho e julho.

1.2. Xyris calostachys Poulsen, Vidensk. Meddel Dansk Naturhist. Foren. Kjobenhavn: 118. 1893

Ervas cespitosas, perenes, base bulbiforme. Folhas dísticas a subdísticas, 11-28,5 cm compr., tortuosas; bainha distintamente alargada, tortuosa, base castanho-escura a quase negra e nítida, margens distintas paleáceas, ciliadas; lâmina filiforme a subcilíndrica, estriada, ápice subuladoacuminado, glabrescente; lígula presente, ca. 1,5 cm compr. Escapo cilíndrico, 27-40 cm compr., sem costela, estriado, glabrescente. Espiga pauciflora, ca. 6 flores, obovóide, 1-1,2 $\mathrm{cm}$ compr., 0,5-0,9 cm larg.; brácteas estéreis 4, castanhoescuras, com mácula larga esverdeada, ocupando quase toda extensão, linear-lanceoladas, 7-12 mm compr., 3,5-4,5 mm larg., as duas mais externas mais longas, subigualando até ultrapassando o comprimento da espiga, carenadas, ápice agudo, excurrente, margens distintas, largas e alvacentas, lacerado-ciliadas especialmente no ápice, tricomas alvos e longos; brácteas florais distintas das brácteas estéreis, 9-11 mm compr., 3-4 mm larg., castanho-escuras, margens largas, alvas e ciliadas. Sépalas laterais levemente exsertas, concrescidas ca. da metade, linear-lanceoladas, ca. $11 \mathrm{~mm}$ compr., inequilaterais, carena estreita, densamente ciliada; estaminódios densamente pilosos; estames ca. 3,5 mm compr. Placentação central-livre.

\section{Kral et al. 72687 (SP, SPF); Wanderley et al. 833 (SP), 841 (SP).}

Espécie referida anteriormente apenas para Diamantina e Serra do Cipó, Minas Gerais, sendo aqui referida pela primeira vez para Grão Mogol. X. calostachys, como significa o epíteto específico (calo= bonito: stachys=espiga) é uma das espécies com espigas mais ornamentais, destacando-se pelas brácteas estéreis muito longas, algumas vezes ultrapassando o comprimento total da espiga. As brácteas de cor castanha e de margens largas, alvas e distintamente ciliadas e a presença de mácula conspícua esverdeada são características que destacam esta espécie das demais estudadas no presente trabalho. É mais relacionada morfologicamente a $X$. insignis A.L. Nilsson pela base bulbiforme e folhas com bainhas bem distintas das lâminas lineares de ápice subulado e atenuado.

Flores em julho.

1.3. Xyris fallax Malme, Bih. Kongl. Svenska Vetensk.Akad. Handl. 22(2): 12. 1896.

Ervas cespitosas, perenes, rizomatosas, rizoma subvertical nas plantas aquáticas. Folhas 12-14 cm compr.; bainha pouco alargada, avermelhada, fortemente estriada, carenada, margens membranáceas; lâmina achatada, 1-3 mm larg., algumas vezes estriada, ápice longamente atenuado e recurvado, margens espessadas e glabras; lígula inconspícua. Escapo cilíndrico, 23-43 cm compr., em geral multicostelado, ruguloso; espata 10-12 cm, margens membranáceas, lâmina muito curta, ápice carenado e assimétrico-acuminado. Espiga multiflora, elipsóide a ovóide, 1-1,5 cm compr., 0,8-1 cm larg.; brácteas estéreis 6 , castanhas, com mancha verde-acinzentada conspícua, 2-6 mm compr., 2-4 mm larg., as 2 mais externas muito curtas, triangulares a largo-ovadas; brácteas florais com ápice agudo, levemente reflexo, margens inteiras a pouco laceradas. Flores com sépalas laterais livres, lanceoladas, ca. 4,5 mm compr., carena estreita, ciliado-fimbriada, tricomas mais longos no ápice; estaminódios pilosos; ovário ovóide; estigmas pouco alargados. Placentação parietal. Fruto ovóide; sementes ca. 1,5 mm, fusiformes, reticuladas.

Hensold et al. CFCR 3531 (SP, SPF); Wanderley et al. 838 (SP).

Distribui-se desde a Venezuela até o Brasil, onde ocorre do Norte até o Sudeste. Em Grão Mogol foi encontrada à beira do rio das Mortes. Juntamente com X. laxifolia Mart., pertencem à Seção Xyris, caracterizada pela placentação parietal. 
1.4. Xyris glaucescens Malme, Repert. Spec. Nov. Regni Veg. 5: 103. 1908.

Ervas cespitosas, perenes, rizomatosas, rizoma curto a desenvolvido. Folhas subdísticas, 7-32 cm compr.; bainha alargada, orbicular, base castanha e inconspicuamente ciliada, carenada, rugulosa; lâmina submembranácea, glauca, achatada, 2-5 mm larg., superfície pouco a muito rugulosa, ápice assimétrico, agudo, margens espessadas e inconspicuamente escabras; lígula inconspícua, ca. $1 \mathrm{~mm}$ compr. Escapo cilíndrico, 30-72 cm compr., 2- a multicostelado, costelas inconspicuamente escabras; espata $10-13 \mathrm{~cm}$ compr., lâmina ca. $1 \mathrm{~mm}$ compr. Espiga multiflora, ovóide a globosa, 5-10 mm compr., 3-4 mm larg.; brácteas estéreis 4, ovadas, 5-6 $\mathrm{mm}$ compr., $3 \mathrm{~mm}$ larg., castanhas, com mancha esverdeada fusiforme conspícua, ocupando grande parte da face dorsal, margens íntegras, as 2 mais externas, em geral, conspicuamente carenadas; brácteas florais elípticas, 7-8 mm compr., 3 $\mathrm{mm}$ larg., com mancha esverdeada, margens íntegras. Flores com sépalas laterais conatas até a metade, oblongo-lanceoladas, ca. $7 \mathrm{~mm}$ compr., 1,5 mm larg., carena densamente pilosa, tricomas alvos; estaminódios pilosos. Placentação central-livre. Fruto obovóide; sementes globosas, ca. 0,5 mm compr., fortemente estriadas, apiculadas. (Fig. 1. J)

Kral \& Wanderley 72683, 72700, 72702 (SP, SPF); Mamede et al. CFCR 3464 (SP, SPF); Mello-Silva \& Pirani CFCR 10757 (SP, SPF); Oliveira et al. CFCR 12914 (SP, SPF); Wanderley et al. 848 (SP), 854 (SP), 859 (SP, SPF).

Xyris glaucescens é uma espécie comum nos campos rupestres de Minas Gerais, ocorrendo em Grão-Mogol em solos brejosos e arenosos, nos vales do rio Itacambiruçu e no riacho Ribeirão. Foi descrita por Malme (1908), posteriormente, em 1913, este mesmo autor considerou-a como uma variedade de $X$. trachyphylla Mart., apresentando a nova combinação $X$. trachyphylla var. glaucescens Malme, que foi aceita por Smith \& Downs (1968). Xyris glaucescens e X. trachyphylla são dois táxons muito relacionados morfologicamente pela presença de folhas em geral estriadas e escabras, placentação central-livre e brácteas com mancha conspícua na superfície dorsal. Entretanto, analisando as coleções de herbário e os protólogos destes dois táxons, além das plantas no seu ambiente natural, verificase que as mesmas são duas espécies distintas, sendo aqui proposto o restabelecimento de Xyris glaucescens Malme. Esta espécie apresenta ampla variação morfológica com relação à espiga e folhas, assim como $X$. trachyphylla, espécie também muito polimórfica e abundante nos campos rupestres de Minas Gerais e da Bahia. Porém, as duas espécies podem ser separadas por um conjunto de características, como coloração e ornamentação da superfície da bainha foliar e morfologia da lâmina e do escapo. Em X. trachyphylla a bainha é caracteristicamente castanho-escura a quase negra e, em geral, fortemente transverso-rugulosa, com margens escabro-ciliadas e a lâmina é verdeescura a arroxeada, fortemente escabra com ápice assimétrico e subobtuso. Xyris glaucescens, por outro lado, apresenta bainha de coloração mais clara, pouco rugulosa, lâmina glauca, fortemente nervada e rugulosa, com margens inconspicuamente escabras e ápice agudo. O escapo em $X$. glaucescens é, em geral, multicostelado, sendo 1 a 2-costelado em $X$. trachyphylla. Flores e frutos entre maio e julho.

\subsection{Xyris graomogolensis Wand. \& Kral, sp. nov.}

Xyris obcordata Kral \& Wanderley foliis ciliatis, sepalis lateralibus liberis et placentatione basali affinis, sed foliis laminis castaneo-rubescentibus, sepalis lateralibus apice rubescenti et bracteis sterilibus fortiter carenatis, maculis rubescentibus vel viridibus munitis, marginibus fortiter laceratis et rubris, interioribus aristatis, paulo minoribus ad aequantes duabus bracteis sterilibus internis differt.

TYPUS. Brasil. Minas Gerais: Grão-Mogol, Vargem do Quartel, 8 km WSW, elev. 500-650 m, M.G.L. Wanderley, R. Kral \& T.M. Cerati 847, 9.VII.1985 (holotypus SP; isotypus SPF).

Ervas cespitosas, perenes, rizomatosas, sub-bulbiformes. Raízes espessas. Folhas espiro-dísticas, $4-15 \mathrm{~cm}$ compr.; bainha com base fortemente alargada, orbicular, margens membranáceas, castanho-escuras e glabras, superfície estriada e inconspicuamente rugosa; lâmina castanho-avermelhada, linear, achatada, 2-4 mm larg., margens espessadas e ciliadas, tricomas longos, superfície nervada, ápice uncinado; lígula ausente. Escapo subcilíndrico, castanho-avermelhado, 10-55 cm compr., 1-2-costado, costas conspícuas, ciliadas, estriado, conspicuamente ruguloso ou escabro; espata conduplicada, ca. $11 \mathrm{~cm}$ compr., carenada, margens ciliadas, lâmina curta, ca. $4 \mathrm{~mm}$ compr., ápice uncinado. Espiga multiflora (ca. 10 a 12 flores), ovóide a obovóide, 4-8 mm compr., 2-6 $\mathrm{mm}$ larg.; brácteas estéreis 4 , castanho-avermelhadas, com mancha oval conspícua avermelhada a esverdeada, ampla, ca. $1 / 3$ da área nas estéreis, margens vermelhas e laceradas, 3-5 mm compr., 2-3 mm larg., as 2 mais externas subigualando as internas, rômbicas, fortemente aristadas e carenadas, as internas obovadas; brácteas florais com mancha e carena na porção superior, obovadas, 4-6 mm compr., 3-4 mm larg., ápice agudo, margens laceradas no ápice. Flores com sépalas laterais livres, fortemente curvas, lanceoladas, 5-6 mm compr., ca. $1 \mathrm{~mm}$ larg., inequilaterais, carena larga, lacerado-fimbriada, agudas; estaminódios pilosos. Placentação basal. Sementes elípticas, estriadas, ca. 0,5 mm compr. (Fig. 3. A-H)

Paratypi. Brasil. Minas Gerais: Grão-Mogol, Vargem do Quartel, ca. 7 km WSW de Grão-Mogol acima do rio Itacambiruçu, R.Kral et al.72689, 9.VII.1985 (SP, SPF); Mello-Silva et al. CFCR 8435, 4.IX.1985 (SPF, SP); Vargem do Quartel, 8 km WSW, elev. 500-650 m, M.G.L. Wanderley et al. 861, 10.VII.1985 (SP).

Espécie encontrada até o momento apenas em Grão-Mogol, ocorrendo em solos úmidos às margens de rios.

Xyris gramogolensis apresenta afinidades $\operatorname{com} X$. obcordata Kral \& Wand. pela presença de folhas ciliadas, espigas 
ovóides a subglobosas e sépalas laterais livres, entretanto difere pelas folhas com lâmina castanho-avermelhada, sépalas laterais com ápice avermelhado e brácteas estéreis fortemente carenadas, com mancha avermelhada ou verde, margens fortemente laceradas e vermelhas, sendo as duas mais externas aristadas, pouco menores até igualando as duas estéreis internas em $X$. graomogolensis. Entretanto, em X. obcordata as folhas apresentam bainha estramínea, lâmina verde-clara, brácteas estéreis em geral com mancha conspícua, margens íntegras a pouco laceradas e placentação suprabasal. O escapo das duas espécies são também distintos, com a presença de duas costelas conspícuas em $X$. graomogolensis e duas costelas ciliadas em $X$. obcordata.

Flores e frutos em julho e setembro.

\subsection{Xyris hymenachne Mart., Flora 24(2): 55. 1841.}

Ervas cespitosas, perenes, curto-caulescentes, base não espessada. Folhas dísticas a espiraladas, retas, ca. 7-14 cm compr.; bainha com base escura e alargada, margens delicadas, às vezes ciliadas; lâmina achatada, sem forte distinção da bainha, 3-4,5 cm larg., estriada, não rugulosa, ápice agudo a acuminado, margem não espessada, glabra. Escapo cilíndrico, 30-42 cm compr., sem costelas ou algumas vezes indistintamente costelado; espata ca. $10 \mathrm{~cm}$ compr., conduplicada, carenada, com lâmina curta. Espiga multiflora, ovóide a obovóide, 5-7 mm compr., 3-4 mm larg.; brácteas estéreis 4, castanho-escuras, sem mancha, elípticas a obovadas, 5-6 mm compr., 2,5-4 mm larg., margens distintas, membranáceas, alvas, eretas e laceradas, às vezes caducas; brácteas florais elípticas, 3-5 mm compr., 1-3 mm larg. Flores com sépalas laterais livres, inclusas a levemente exsertas, lanceoladas, ca. $5 \mathrm{~mm}$ compr., fortemente inequilaterais, carena ciliadofimbriada; estaminódios pilosos; estame ca. $2 \mathrm{~mm}$ compr., antera sagitiforme. Placentação basal. Sementes numerosas, mais de 50, ca. 0,5 mm compr., estriadas. (Fig. 1. K)

Hensold et al. CFCR 3532 A (SPF); Kral et al. 72700 (SP, SPF); Oliveira et al. 636 (HUEFS, SP).

Ocorre do Nordeste ao Sul do Brasil. Muito comum nos campos rupestres brasileiros de Minas Gerais e Bahia. Em Grão-Mogol foi encontrada em solos arenosos e úmidos ou em ambientes de cerrado. Apresenta ampla variabilidade quanto à morfologia da planta e das espigas.

\subsection{Xyris laxifolia Mart., Flora 24(2): 53. 1841.}

Ervas cespitosas ou isoladas, perenes, caules verticais nas plantas aquáticas. Folhas dísticas, 27-55 cm compr.; bainha castanho-arroxeada, base alargada, opaca, margem estreita, hialina e glabra, algumas vezes estriada; lâmina achatada, levemente estriada, às vezes com estrias avermelhadas, ápice agudo, margens glabras; lígula ausente. Escapo subcilíndrico, 61,5-120 cm compr., em geral sem costelas a 1-costelado, liso ou com pontuações vermelhas; espata conduplicada, ca. $20 \mathrm{~cm}$ compr., carenada no ápice, lâmina curta. Espiga multiflora, ovóide a elipsóide, $1,7 \mathrm{~cm}$ compr., $1 \mathrm{~cm}$ larg.; brácteas estéreis ca. 8 , castanho-escuras, com mancha ovada, verde-acinzentada e conspícua, ovadas a obovadas, 3-10 mm compr., 3-6 mm larg., brácteas externas mais curtas e carenadas; brácteas florais ovadas a orbiculares, ca. $10 \mathrm{~mm}$ compr., $5 \mathrm{~mm}$ larg., margens pouco laceradas. Flores com sépalas laterais inclusas, livres, ca. 5,5 $\mathrm{mm}$ compr., subequilaterais, estreito-espatuladas a lanceoladas, carena estreita, glabra na base, ciliado-fimbriada para o ápice; estaminódios densamente pilosos; estigmas alargados. Placentação parietal. Fruto obovóide; sementes opacas, reticuladas, estrias longitudinais conspícuas, ápice acuminado.

\section{Wanderley et al. 465 (SP).}

Espécie de ampla distribuição, ocorrendo em toda a América tropical até a Argentina. Habita solos brejosos, ricos em matéria orgânica ou solos arenosos. É encontrada, ainda, em bordas de matas e ambientes perturbados de solos úmidos ou alagados. Em Grão-Mogol habita campo adjacente a cerrado.

1.8. Xyris obcordata Kral \& Wand., Ann. Missouri Bot. Gard. 75(1): 361. 1988.

Ervas densamente cespitosas, perenes, rizomatosas, algumas vezes rizoma subvertical, especialmente nos indivíduos de solos encharcados. Folhas subdísticas, 6-10 cm compr.; bainha com base alargada, carenada, margens ciliadas; lâmina achatada, 3-4 mm larg., superfície lisa a inconspicuamente rugulosa, ápice assimétrico, agudo, margens densamente ciliadas; lígula inconspícua. Escapo cilíndrico, 30-40 cm compr., sem costelas a 1-2-costelado, costelas ciliadas a glabrescentes; espata ca. $10 \mathrm{~cm}$ compr. Espiga multiflora, ovóide a subglobosa, 4-6 mm compr., 3-5 mm larg.; brácteas estéreis 4, com mancha esverdeada ou avermelhada, obovadas, oblongas, 3-6 mm compr., 4-5 mm larg., ápice algumas vezes emarginado, margens íntegras a pouco laceradas, glabras; brácteas florais elípticas a obovadas, 4-6 $\mathrm{mm}$ compr., 2-4 mm larg., carenadas. Flores com sépalas laterais livres, oblongo-espatuladas, 4-5 mm compr., ca. $1 \mathrm{~mm}$ larg.; estaminódios pilosos. Placentação suprabasal. Sementes elípticas, ca. 0,5 mm compr. (Fig. 1.H-I).

Cordeiro et al. CFCR 730 (SP, SPF), 780 (SP, SPF), CFCR 802 (SP, $\mathrm{SPF})$; Pirani et al. 4574, 4588 (SPF).

Espécie de ocorrência nos campos rupestres de Minas Gerais. Em Grão-Mogol ocorre em solo arenoso-paludoso, próximo ao rio Itacambiruçu. Apresenta grande afinidade morfológica com $X$. pterygoblephara Steud. pelas espigas ovóides a globosas e folhas com lâmina densamente ciliadas. A placentação suprabasal observada em $X$. obcordata difere da descrição original, onde é referida placentação central. Este caráter é às vezes de interpretação confusa pela presen- 


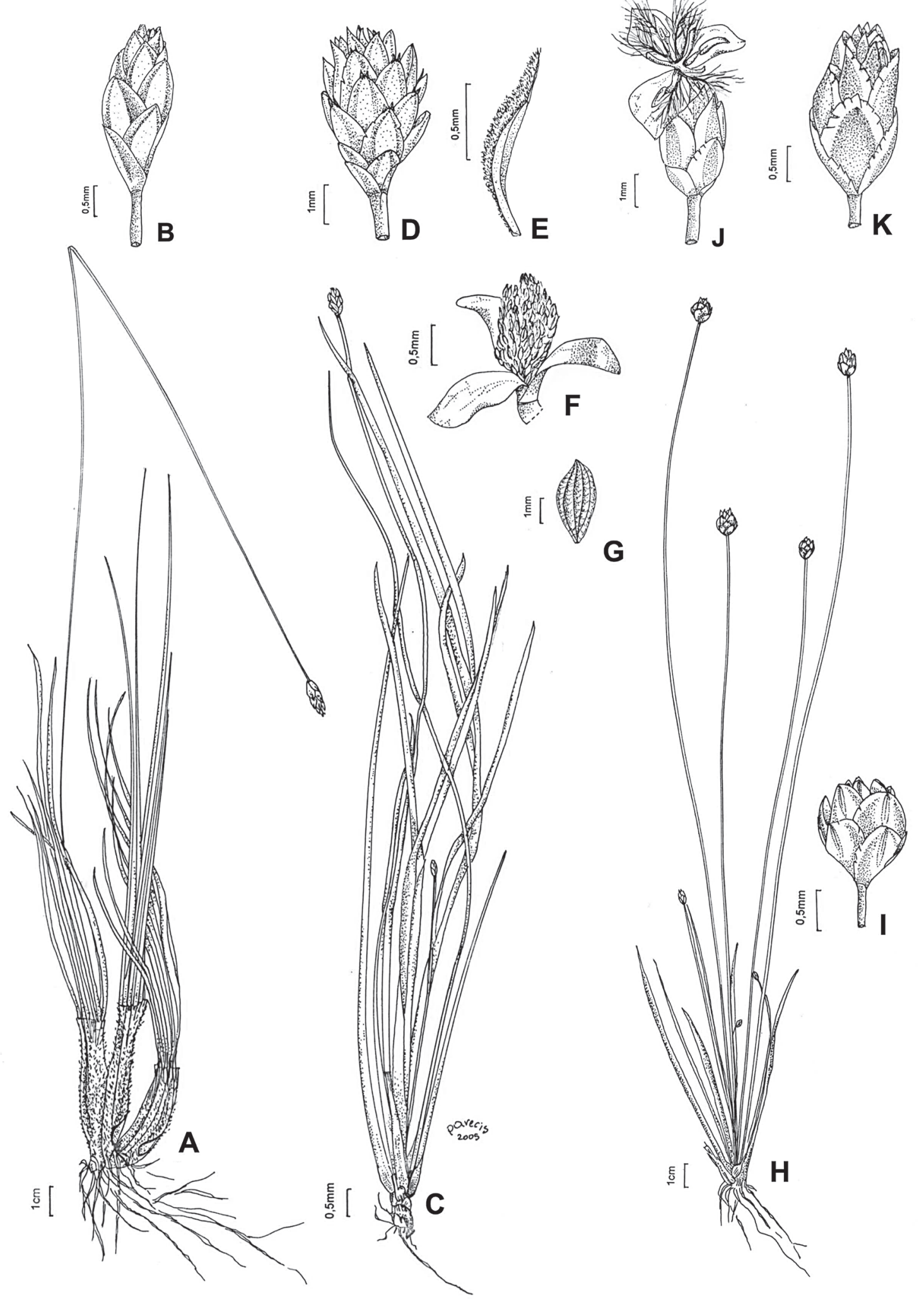

Fig. 1. XYRIDACEAE. A-B. Xyris sp. 1: A. hábito, B. espiga. C-G. X. trachyphylla: C. hábito, D. espiga, E. sépala lateral, F. fruto aberto com numerosas sementes, G. semente com superfície estriada. H-I. X. obcordata: H. hábito, I. espiga. J. X. glaucescens: espiga. K. X. hymenachne: espiga. (A-B. Kral et al. 72707; C-G. Wanderley 836; H-I. Cordeiro et al. CFCR 780; J. Oliveira et al. CFCR 12914; K. Kral et al.72700). 
ça de funículos longos e parcialmente concrescidos na base, formando um curto eixo, simulando o tipo de placentação central-livre. Coletada em flor em março e abril.

1.9. Xyris pteryogobephlara Steud., Syn. pl. glumac. 2: 285. 1855.

Ervas densamente cespitosas, perenes, rizomatosas, algumas vezes rizoma subvertical, especialmente nos indivíduos de solos encharcados. Folhas subdísticas, 4-22,5 cm compr.; bainha com base alargada, orbicular, escura, carenada, margens ciliadas; lâmina achatada, 1-5 mm larg., superfície lisa a inconspicuamente rugulosa, ápice assimétrico, agudo, margens densamente ciliadas; lígula inconspícua. Escapo cilíndrico, 13$30 \mathrm{~cm}$ compr., sem costelas a 1-2-costelado, costelas ciliadas a glabrescentes; espata 4-7 cm compr. Espiga multiflora, ovóide a subglobosa, 3-14 mm compr, 3-10 mm larg.; brácteas estéreis 4, obovadas, oblongas, 3-6 mm compr, 4-5 mm larg., com ou sem mancha na face dorsal das brácteas, mancha apical esverdeada ou avermelhada, ápice algumas vezes emarginado, margens íntegras a pouco laceradas, glabras; brácteas florais elípticas a obovadas, 4-6 mm compr, 2-4 mm larg., carenadas. Flores com sépalas laterais livres, oblongo-lanceoladas, 4-5 mm compr., ca. $1 \mathrm{~mm}$ larg.; estaminódios pilosos. Placentação basal. Sementes elípticas, ca. $0,5 \mathrm{~mm}$ compr.

Cavalcanti et al. CFCR 9656 (SP, SPF); Cerati et al. CFCR 4266 (SP, SPF); Giulietti et al. CFCR 9870 (SPF); Kral et al. 72685 (SP, SPF), 72716 (SPF); Oliveira et al. CFCR 12890, CFCR 13030 (SP, SPF); Pirani \& Mello-Silva CFCR 10758 (SP, SPF); Pirani et al. CFCR 12895 (SP, SPF), 13066 (SPF); Prado et al. CFCR 12039 (SP, SPF); Wanderley et al. 844 (SP).

Muito frequente nos campos rupestres da Cadeia do Espinhaço de Minas Gerais e Bahia. Em Grão-Mogol ocorre em solos arenosos úmidos, algumas vezes parcialmente submersa ou próximo a cerrado. Floresce entre fevereiro e julho.

1.10. Xyris roraimae Malme, Notizbl. Königl. Bot. Gart. Berlin 6: 117. 1914.

Ervas cespitosas, perenes; caule pouco desenvolvido. Folhas dísticas, retas a pouco tortuosas, $20-26 \mathrm{~cm}$ compr.; bainha alargada, castanho-escura, margens ciliadas; lâmina achatada a ensiforme, $3 \mathrm{~mm}$ larg., ápice agudo, atenuado, encurvado, levemente espessado, margens ciliadas, superfície estriada; lígula inconspícua, ca. $2 \mathrm{~mm}$ compr. Escapo cilíndrico, 60-92 cm compr., 2-costelado, costelas ciliadas; espata conduplicada e carenada, 10-27,5 cm compr., com lâmina curta. Espiga multiflora, ca. 25 flores, elipsóide, ovóide ou cilíndrica, 13-20 mm compr., 7-15 mm larg.; brácteas estéreis 4, castanho-claras, obovadas, 4,5-6 mm compr., 3-4 mm larg., margens distintas, avermelhadas, laceradas, ápice arredondado; brácteas florais obovadas, $7 \mathrm{~mm}$ compr., 5,5 $\mathrm{mm}$ larg., castanho-claras, margens delicadas, ápice arredondado. Flores com sépalas laterais livres, exsertas, espatuladas ou curvas, $0,5 \mathrm{~mm}$ compr., inequilaterais, carena ciliado- fimbriada; estaminódios pilosos. Placentação basal. Fruto obovóide; sementes $0,8 \mathrm{~mm}$ compr., estriadas.

Kral et al. 72705 (SP); Wanderley et al. 858 (SP).

Xyris roraimae ocorre na Venezuela e no Brasil, onde se distribui no Norte, tendo ainda registros para os estados de Goiás, Distrito Federal, Bahia e Minas Gerais. Bem característica pelas espigas vistosas, robustas, ovóides a cilíndricas e brácteas com margens distintas, laceradas e avermelhadas. Apresenta afinidades com X. schizachne Mart. pela morfologia das espigas. Usada como sempre-viva, sendo vendida em feiras livres na cidade de Brasília.

\subsection{Xyris savanensis Miq., Linnaea 18: 605. 1844.}

Ervas em geral solitárias, anuais, caule inconspícuo, base pouco alargada. Folhas dísticas, flabeladas, $2-4 \mathrm{~cm}$ compr.; bainha com base pouco alargada, castanho-avermelhada, margens membranáceas, glabras; lâmina castanha a avermelhada, achatada, 1,5-3 mm larg., ápice agudo a obtuso, superfície rugulosa, margens espessadas, rugulosas ou escabras; lígula inconspícua, aguda. Escapo cilíndrico, 1-2-costelado, costela rugulosa ou escabra, $10-25 \mathrm{~cm}$ compr. Espiga pauci- a multiflora, largo-ovóide, 2-5 $\mathrm{mm}$ compr., 2-5 mm larg., globosa a cilíndrica; brácteas estéreis 4 , com mancha castanho-avermelhada apical, orbiculares, ca. 2-3 mm compr., 2,5-3 mm larg., margens íntegras; brácteas florais com mancha apical, obovadas, $4 \mathrm{~mm}$ compr., $3 \mathrm{~mm}$ larg., margens íntegras a pouco laceradas. Flores com sépalas laterais livres, espatuladas, ca. $3 \mathrm{~mm}$ compr., $1 \mathrm{~mm}$ larg., fortemente inequilaterais, carenadas, carena ciliada; estaminódios glabros. Placentação basal. Sementes castanho-escuras, globosas, 0,4-0,5 mm compr. (Fig. 2. J)

Zappi et al. CFCR 12886 (SPF).

Possui ampla distribuição, ocorrendo desde a Venezuela até a Argentina. No Brasil é encontrada de norte a sul. Em Grão-Mogol, cresce em solos arenosos próximo a rios. Espécie bem característica pela presença de estaminódios glabros, distinguindo-se das demais ocorrentes na região. Apresenta grande variação de tamanho da planta e das espigas. Flores e frutos em julho.

1.12. Xyris seubertii A.L. Nilsson var. espinhacae Kral \& Wand., Ann. Missouri Bot. Gard. 75(1): 368. 1988.

Ervas cespitosas, perenes, rizomatosas. Folhas subdísticas, 3-10 cm compr.; bainha orbicular, base castanho-escura, margens membranáceas, glabras a curto-ciliadas; lâmina achatada, 0,8-3 mm larg., glauca a arroxeada, nervuras marginais espessadas, glabras a ciliadas, ápice atenuado-recurvado; lígula inconspícua. Escapo arroxeado, cilíndrico, 4-35 cm compr., 1-2-costelado, costelas escabras; espata 4-7 cm compr., lâmina curta, ca. 1,5 cm compr., ápice obtuso, atenuado e recurvado. Espiga pauci- (4 flores) a multiflora, ovóide, 
obovóide a globosa , 4-10 mm compr., 3-5 mm larg.; brácteas estéreis 4, oblongas, 5-6 mm compr., 2-3 mm larg., com mancha apical esverdeada a castanha, conspícua a inconspícua, ápice arredondado, em geral pouco excurrente, carenadas, margens laceradas, avermelhadas, ciliado-fimbriadas em direção ao ápice; as duas externas pouco menores que as 2 subsequentes estéreis; brácteas florais oblongas, com mancha apical esverdeada, ápice ciliado-fimbriado. Flores com sépalas laterais conatas até a metade, 6-7 mm compr., ca. 1,5 $\mathrm{mm}$ larg., carenadas, densamente ciliadas, tricomas rígidos, alvos ou avermelhados, ápice aristado; estaminódios densamente pilosos. Placentação central-livre. Fruto obovóide a estreito-ovóide; sementes oblongas a ovóides, reticuladas, ca. $0,5 \mathrm{~mm}$ compr. (Fig. 2. A-I)

Hensold et al. CFCR 3532 (SP, SPF); Irwin et al. 23667 (SP, isótipo de Xyris seubertii var. espinhacae); Kral et al. 72724 (SPF); Maguire et al. 49275 (R); Mello-Silva \& Cordeiro CFCR 10069 (SP, SPF); Oliveira et al. CFCR 13141 (SP, SPF); Wanderley et al. 860 (SP); Zappi et al. CFCR 12998 (SP, SPF).

Xyris seubertii apresenta ampla distribuição geográfica, ocorrendo desde a Venezuela, penetrando pelo Brasil até o Paraguai. No Brasil ocorre da Bahia a Santa Catarina. Em Grão-Mogol foi encontrada apenas a variedade espinhacae, local de ocorrência do tipo desta variedade, onde habita em solos arenosos e úmidos e regiões adjacentes a cerrados, sendo endêmica dos campos rupestres de Minas Gerais. Apresenta ampla variabilidade com relação à forma, tamanho da espiga e número de flores. Alguns exemplares (Wanderley et al. 860) possuem espigas bem menores e com apenas quatro flores e brácteas sem ápice excurrente diferindo do materialtipo da variedade. Entretanto, foi observado um contínuo destas características, evidenciando o polimorfismo deste táxon. Com flores e frutos em fevereiro a setembro.

\subsection{Xyris sincorana Kral \& Wand., Kew Bull. 48(3): 586.} 1993.

Ervas cespitosas, perenes, base bulbiforme. Folhas flexuosas, 11-28 cm compr.; bainha alargada, castanho-enegrecida, margens ciliadas; lâmina cilíndrica a filiforme, ca. 0,5-1 mm larg., ápice longamente atenuado; lígula inconspícua. Escapo flexuoso, cilíndrico, ca. $44 \mathrm{~cm}$ compr., glabro, não costelado; bainha do escapo ca. $10 \mathrm{~cm}$ compr., curto-laminada. Espiga multiflora, ovóide, 7-10 mm compr., $5 \mathrm{~mm}$ larg.; brácteas estéreis 6, lanceoladas a elípticas, $8-10 \mathrm{~mm}$ compr., 1-2 mm larg., as externas estreitas, em geral ultrapassando as demais, margens laceradas; brácteas florais concolores, ovadas, ca. $5 \mathrm{~mm}$ compr., 3-4 mm larg., margens laceradas. Flores com sépalas laterais livres, lanceoladas, ca. $5 \mathrm{~mm}$ compr., $1 \mathrm{~mm}$ larg., equilaterais, carena estreita, ciliolada, ápice agudo, retroflexo; estaminódios pilosos. Placentação basal. Fruto elipsóide; sementes elípticas, castanho-escuras. (Fig. 2. M-N)

Kral et al. 72684 (SP, SPF); Oliveira et al. CFCR 13058 (SP, SPF); Wanderley et al. 846 (SP).
É encontrada na Cadeia do Espinhaço de Minas Gerais e Bahia. Em Grão-Mogol ocorre em solos arenosos e úmidos, próximo ao rio Itacambiruçu. Caracteriza-se pela bainha castanho-escura com fibras desfiadas e as brácteas basais longamente acuminadas. No material de Grão-Mogol, as duas brácteas estéreis igualam ou ultrapassam o comprimento das demais brácteas. Entretanto, no exemplar-tipo ( Kral \& Wanderley 72693), procedente da Bahia, as duas brácteas estéreis mais externas são pouco mais curtas que as demais, diferindo do material examinado de Grão-Mogol, cujas brácteas externas quase igualam as demais Floresce e frutifica em junho e julho.

1.14. Xyris sparsifolia Kral \& L.B. Sm., Bradea 3(34): 279. 1982.

Ervas cespitosas ou isoladas, perenes, rizoma desenvolvido, bulbiformes. Folhas espiraladas, flexuosas, poucas (ca. 6), 6-15 cm compr.; bainha orbicular, base castanhoavermelhada, brilhante, estriada, densamente ciliada; lâmina subcilíndrica, ca. 0,5 $\mathrm{mm}$ larg., margens glabras a pilosas; lígula inconspícua. Escapo cilíndrico, sem costelas, torcido, estriado, 28,5-50 cm compr., glabro; bainha ca. $6 \mathrm{~cm}$ compr., lâmina conspícua, 1-1,2 cm compr. Espigas cilíndricas, 8-15 $\mathrm{mm}$ compr., 6-7 $\mathrm{mm}$ larg.; brácteas estéreis 8 , com mancha estreito-ovada, castanha, conspícua a inconspícua, oblongas a obovadas, 2-4 mm compr., 1-3 mm larg., margens íntegras, as 2 externas conspicuamente mais curtas; brácteas florais elípticas a obovadas, 3-4 mm compr., 1-3 mm larg., carenadas, margens íntegras. Flores com sépalas laterais livres, oblongo-elípticas, 4,5-5 mm compr., ca. $1 \mathrm{~mm}$ larg., inequilaterais, carena lacerada na parte mediana, ápice obtuso e ciliado; estaminódios pilosos. Placentação basal. Sementes oblongas, ca. 1 mm compr. (Fig. 2. K-L)

Mamede et al. CFCR 3408 (SPF); Mello-Silva et al. CFCR 9655 (SP, SPF); Pirani \& Mello-Silva et al. CFCR 10831 (SP, SPF).

É encontrada na Cadeia do Espinhaço de Minas Gerais, e na Serra do Sincorá na Bahia. Em Grão-Mogol ocorre em pequenas populações, em terrenos arenosos e úmidos à beira de córregos. Espécie caracterizada pelo escapo torcido e espiga cilíndrica. Flores entre fevereiro e maio.

\subsection{Xyris tenella Kunth, Enum. pl. 4: 9.1843.}

Ervas cespitosas, perenes, sub-bulbiformes. Folhas espiraladas, $15-25 \mathrm{~cm}$ compr.; bainha alargada, densamente ciliada, tricomas longos; lâmina ferrugínea, cilíndrica, 0,5$0,8 \mathrm{~mm}$ larg., rugulosa ou escabra, glabras; lígula ausente. Escapo cilíndrico, 30-45 cm compr., 1 a multicostelado, conspicuamente escabro. Espiga pauciflora, ovóide a obovóide, ca. $7 \mathrm{~mm}$ compr., 3-4 $\mathrm{mm}$ larg.; brácteas estéreis 4 , castanhas, com mácula inconspícua e apical, ovadas a oblongas, ca. $5 \mathrm{~mm}$ compr., 3-4 mm larg., ápice obtuso a agudo, margens distintas, alvacentas, membranáceas, laceradas e caducas; brácteas florais oblongas, 7-8 mm compr., 5-6 mm larg., membranáceas. Flores com sépalas laterais livres, lan- 

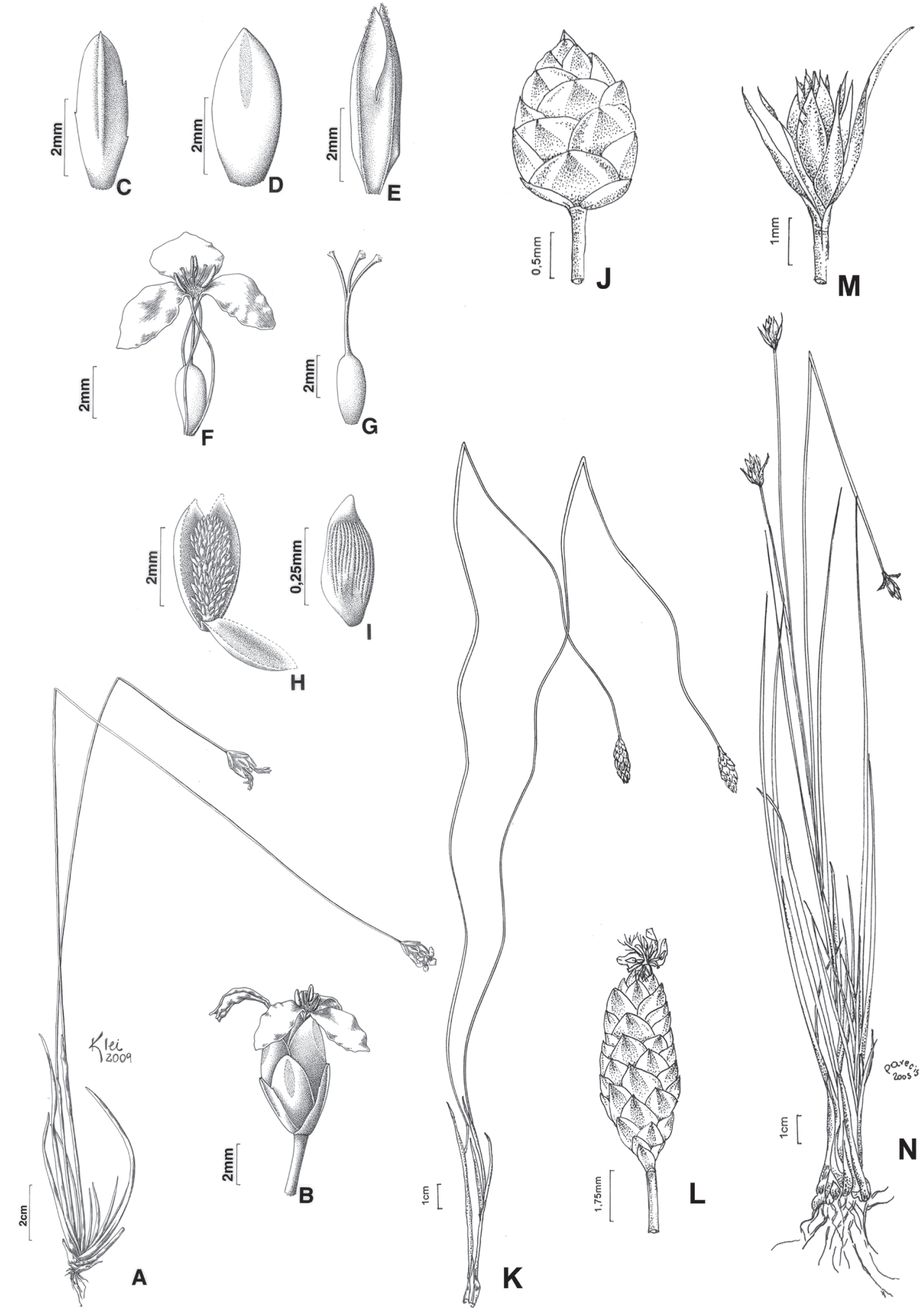

Fig. 2. XYRIDACEAE. A-I. Xyris seubertii var. espinhacae: A. hábito, B. espiga, C. bráctea estéril carenada, D. bráctea floral, E. sépalas laterais concrescidas, F. flor sem as sépalas, G. gineceu, H. fruto aberto mostrando placentação central-livre, I. semente. J. X. savanensis: espiga. K-L. X. sparsifolia: K. hábito, L. espiga. M-N. X. sincorana: M. espiga, N. hábito.(A-I. Wanderley et al. 860; J. Zappi et al. CFCR 12886; K-L. Pirani \& Mello-Silva CFCR 10831; M-N. Wanderley et al. 846). 


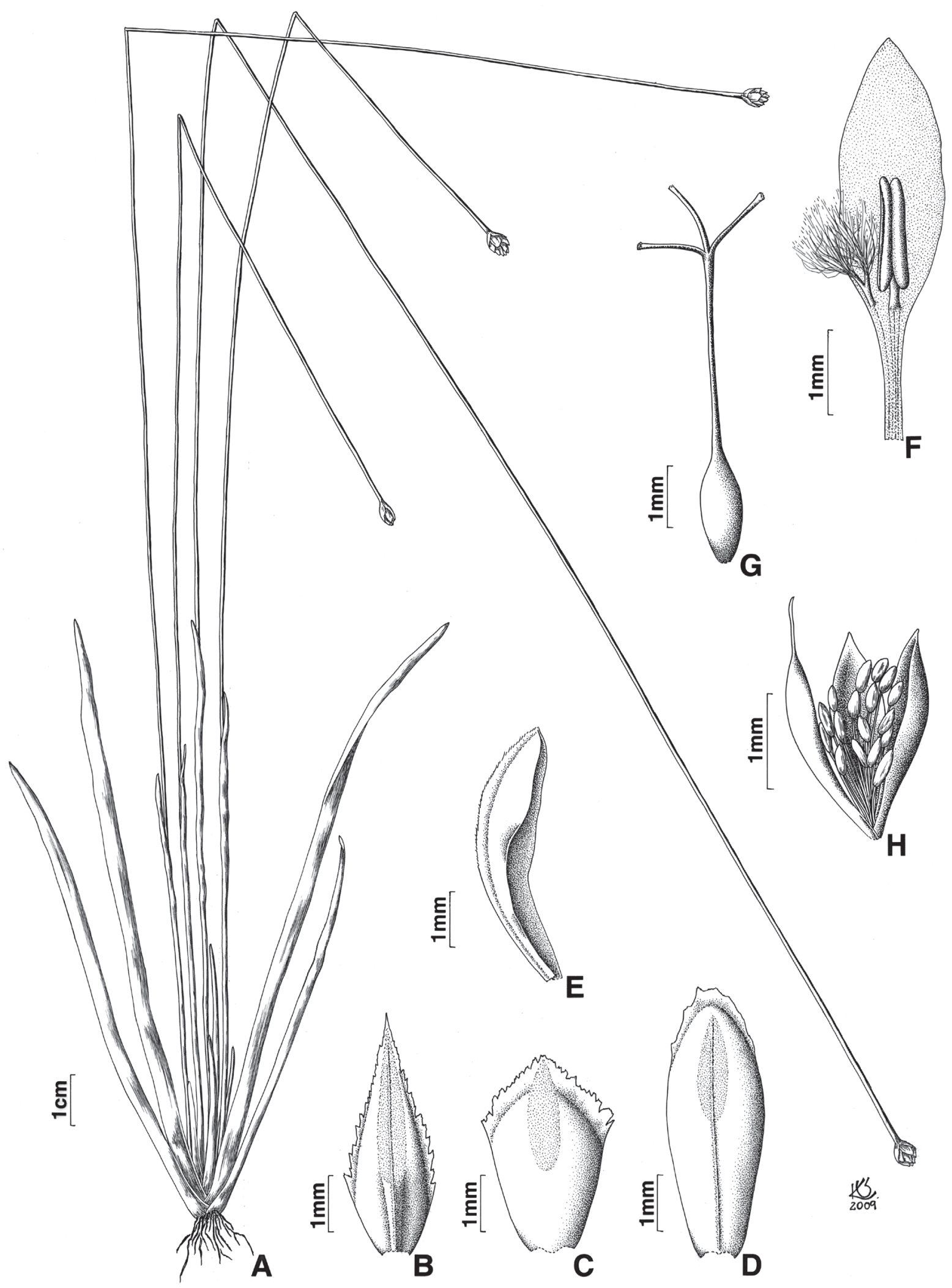

Fig. 3. XYRIDACEAE. A-H. Xyris graomogolensis: A. hábito, B. bráctea estéril externa, C. bráctea estéril, D. bráctea floral, E. sépala lateral, F. pétala com estame e estaminódio piloso, G. gineceu, H. cápsula aberta mostrando placentação central-livre e sementes. (A-H. Wanderley et al. 847). 
ceoladas, ca. $7 \mathrm{~mm}$ compr., $1 \mathrm{~mm}$ larg., inequilaterais, carena estreita, ciliada; estaminódios pilosos. Placentação basal. Sementes elípticas, ca. 0,5 $\mathrm{mm}$ compr.

Hatschbach 41368, 42868 (SP); Kral et al. 72709 (SP, SPF); Giulietti et al. CFCR 3428 (SPF).

A espécie distribui-se desde a Venezuela até o Paraguai e no Brasil ocorre de Norte a Sul. Possivelmente o material de Grão-Mogol trata-se de uma nova variedade de X. tenella, pela presença de escapo multicostelado e conspicuamente escabro, necessitando estudos mais aprofundados. Em GrãoMogol ocorre em solo arenoso e úmido, na Serra do Piripiri e próximo ao rio Itacambiruçu. Espécie caracterizada pela densa pilosidade das margens da bainha e lâmina cilíndrica. Coletada com flores em julho.

\subsection{Xyris tortula Mart., Flora 24(2): 55. 1841}

Ervas perenes, cespitosas, base bulbiforme. Folhas espiraladas, $11,5-30,5 \mathrm{~cm}$ compr., torcidas; bainha alargada, castanho-escura, margens ciliadas; lâmina achatada, filiforme a subcilíndrica, $5 \mathrm{~mm}$ larg., glabra, superfície lisa a transversorugulosa; lígula ausente. Escapo cilíndrico, $34-40 \mathrm{~cm}$ compr., 1-costelado, estriado. Espigas paucifloras, ca. 10 flores, ovóide, 5-8 mm compr., 4-5 mm larg.; brácteas estéreis 4, ovadas a obovadas, castanho-escuras, brilhantes, 3,8-5 mm compr, ca. $2 \mathrm{~mm}$ larg., carena presente ou ausente, margens distintas, laceradas e membranáceas. Flores com sépalas laterais inclusas a levemente exsertas, livres, 5,2 mm compr., 2,5 mm larg.; estaminódios densamente pilosos. Placentação basal. Sementes estriadas, ca. 0,9 mm compr.

Kral et al. 72709 (SP, SPF); Wanderley et al. 857 (SP).

Xyris tortula é uma espécie exclusivamente brasileira, ocorrendo desde Minas Gerais até o Rio Grande do Sul. Em Grão-Mogol ocorre em solos arenosos e úmidos próximo ao rio Itacambiruçu.

\subsection{Xyris trachyphylla Mart., Flora 24(2): 56. 1841.}

Ervas cespitosas, perenes, rizomatosas, rizoma curto. Folhas espiro-dísticas, 10-32 cm compr.; bainha castanho-escura a arroxeada, alargada, carenada, escabra; lâmina achatada, ca. $2 \mathrm{~mm}$ larg., fortemente escabra a rugulosa; lígula conspícua, ca. $4 \mathrm{~mm}$ compr. Escapo cilíndrico a levemente comprimido, 47-66 cm compr., 1-costelado, escabro, conspicuamente transverso-ruguloso; espata 12-15 cm compr., lâmina ca. 2,2 $\mathrm{cm}$ compr. Espiga multiflora, ovóide a obovóide, 8-20 mm compr., 5-10 mm larg.; brácteas estéreis 4, coriáceas, com ampla mancha ocupando a maior parte da superfície dorsal da bráctea, ovado-oblongas, 4-4,5 $\mathrm{mm}$ compr., 3-3,5 mm larg., cocleadas, ápice obtuso e fimbriado-ciliado, margens membranáceas, laceradas e ciliado-fimbriadas; brácteas florais oblongas, 15-18 mm compr., 4-5 mm larg., com mancha ovada, verde-acinzentada, conspícua. Flores com sépalas laterais conatas na base, oblongas, $8 \mathrm{~mm}$ compr., inequilaterais, ca- rena densamente pilosa, tricomas avermelhados e retorcidos; estaminódios densamente pilosos. Placentação central-livre. Sementes irregularmente reticuladas. (Fig. 1. C-G)

Kral et al. 72686, 72704 (SP, SPF); Wanderley et al. 836 (SP).

Encontrada até o momento em Grão-Mogol, habitando solos arenosos próximos ao rio Itacambiruçu. Espécie bem característica pela presença de folhas e escapos fortemente escabros e brácteas com mancha conspícua. Apresenta afinidades morfológicas com Xyris diamantinae Malme pelas folhas rugulosas, com bainhas castanho-escuras a arroxeadas e placentação central-livre, mas difere pela morfologia da espiga e brácteas e pelas folhas e escapo fortemente escabros. Com flores em julho.

\subsection{Xyris sp. 1}

Ervas cespitosas, perenes, rizomatosas, rizoma robusto. Folhas espiro-dísticas, 9-28 cm compr.; bainha alargada, carenada, base castanho-escura, margens densamente ciliadas, tricomas longos e vilosos formando uma densa trama; lâmina achatada, verde a castanha, 1-3 mm larg., estriada, ápice longo-atenuado, margens escabro-ciliadas; lígula inconspícua. Escapo cilíndrico, 32,5-68 cm compr., ruguloso, 1-costelado, costela escabra; espata ca. $16 \mathrm{~cm}$ compr., lâmina curta, ca. $1 \mathrm{~cm}$ compr. Espiga multiflora, ovóide, 9-12 mm compr., 4,5$7 \mathrm{~mm}$ larg.; brácteas estéreis 4, castanho-escuras, com mancha dorsal fusiforme, avermelhada, conspícua a inconspícua, ocupando grande parte da face dorsal, oblongas ou obovadas, 4-7 mm compr., 2-3 mm larg., carenadas, ápice acuminado, levemente excurrente, margens inteiras a pouco laceradas, as 2 mais externas pouco menores que as 2 subjacentes internas, fortemente carenadas; brácteas florais elípticas a oblongas, ca. $6 \mathrm{~mm}$ compr., 3-5 mm larg., ápice carenado e levemente excurrente, glabro a ciliado, margens inteiras. Flores com sépalas laterais conatas no terço inferior, ca. $6 \mathrm{~mm}$ compr., $1 \mathrm{~mm}$ larg.; estaminódios pilosos. Placentação central-livre. Sementes elípticas, ca. 0,8 cm compr. (Fig. 1. A-B)

Bida et al. CFCR 12002 (SP, SPF); Hatschbach 41324 (SP); Hensold et al. CFCR 3570 (SP, SPF); Kral et al.72707 (SP, SPF); MelloSilva et al. CFCR 9926 (SP, SPF); Pirani \& Mello-Silva CFCR 10769 (SP, SPF); Simão-Bianchini et al. CFCR 12908 (SP, SPF); Wanderley et al. 845 (SP, SPF); Zappi et al. CFCR 12841 (SPF, SP).

Coletada até o momento em Grão-Mogol em solos arenosos e úmidos e entre rochas, no vale do rio Itacambiruçu, rio das Mortes e córrego Escurona, formando, em geral, densas populações. Distingue-se das demais espécies da região pela densa pilosidade das margens das bainhas, tornando as folhas fortemente agregadas pela trama formada com longos tricomas. Apresenta certa afinidade morfológica com $X$. insignis L.A. Nilsson pelas características das espigas, entretanto é bastante distinta desta espécie, especialmente pela parte vegetativa. Possivelmente trata-se de uma nova espécie, necessitando estudos complementares para confirmação dessa hipótese. Flores e frutos entre maio e julho. 